\title{
LEARNING MOTIVATION AND PERCEPTION OF THE TEACHERS' PEDAGOGIC COMPETENCE AND LEARNING ACHIEVEMENT IN SOCIAL SCIENCE OF JUNIOR HIGH SCHOOL STUDENTS
}

\author{
Konstantinus Dua Dhiu \\ STKIP Citra Bakti, Nusa Tenggara Timur, Indonesia \\ Email: konstantinusdua@ymail.com
}

\begin{abstract}
This present study aims at investigating the relation between learning motivation and junior secondary level students' learning achievement in social science, figuring out the relation between learning motivation and teachers' pedagogic competence toward the students learning achievement. A number of 70 students are randomly selected as the sample of this study. The data are collected through questionnaire. This study reveals that; 1) the positive and significant relation between learning motivation altogether with teachers' pedagogic competence and students learning achievement in social science subject, 2) a positive and significant relation between learning motivation and the perception of teachers' pedagogic competence toward the students learning achievement in social science subject.
\end{abstract}

Keywords: learning, motivation, pedagogic, achievement

\section{Introduction}

Teachers have multiple roles such as professionalism roles, roles in humanity, as well as in social roles. Specifically, their roles in professionalism cover educating, teaching, and also training. As for their roles in humanity, they have roles to be parents, partner, and problem solver for students. And, their social roles encompass educating people to be a good citizen.

Teachers are also known as human source that have strategic position to establish the success of educational programme. Teachers are the human factor that has a close relation to learners in teaching and learning process as well as in daily interaction in school. As a profession, teachers need to fill themselves with specific criteria such as knowledge and skills. They need to know basics in teaching, knowledge in specific subject so that they can run their duties competently. Thus, it leads them to be a professional teacher.

Generally, there are three stages to determine the quality of teacher's professionalism. The first stage is called personally capable. This means teachers are expected to have proper knowledge, skills and also attitude to manage the teaching and learning process effectively. The second stage is teacher as innovator. This means teachers have to have great commitment by any means of change and reformation. The third step is teacher as developer which focuses on how teachers should have a prospective vision.

The success of education from the aforementioned factors lies on the teachers and students as the doer. From teacher point of view, teachers' professionalism and capability are compulsory as basics to transfer knowledge. While from students' side, their will and effort in participating in every activity are needed as basics in social life due to their ability in brain processing, thus human can create world by stating their own standard, value, and the strategy to achieve it.

Basically, learning process aims at producing positive innovation toward maturity. These changes show that there is an achievement after the learning process. Learning achievement is known as the result of practicing and guiding between students and the teacher as facilitator. The fact shows that there are teachers who are not able to create such a conducive learning atmosphere. This problem generates an antipathy from students to teacher and degrading their motivation to learning a specific subject.

Achievement is a term which is closely related to quality, productivity, and output from somebody's effort or group of people (Kirkpatrik \& Lewis, 1995:8). In addition, Gunawan (1996:65) states that achievement is a result from hard work from a person. Achievement is also a result from interaction among some factors like the effort and the ability to do something and followed by some other factors such as other people and facilities.

A support in the process of achieving determines someone's determination. Someone will have a good achievement if $s / h e$ is highly motivated. Winkel argues that motivation is a stimulus within somebody's mind to achieve his/her target and to participate where s/he thinks that is suitable for them. This stimulus is a personal characteristic as a result from brain development within a period of time. 
In short, learning achievement is related to hard work and effort to get better. The inner motivation is a stimulus for creating an effective activity. According to William Burton, teaching is a guidance of learning activities, teaching is for purpose of aiding the pupil to learn. Therefore, the students activity are put into consideration more than passive activity because students are the subject and they have the right to be involved in deciding and planning the learning activity (Usman, 2000: 16).

On the other hand, the significance of learning also lies on its process and elements in every level. This means that the success and failure of the purpose of learning depend much on the learning process. Therefore, comprehending the core of learning and its aspects become essential. Mistakes and incomplete perception to the process of learning will degrade the quality of learning itself. The concept of learning refers to three aspects, namely learning as a process, learning as a product, and learning as a function. Learning as a process means a movement or driving someone's attitude. Learning as a product emphasizes on the result from experiencing a new situation. The experience can be in form of attitude, knowledge, or skills to do a particular task. Accordingly, learning as a function emphasizes on the aspects that influence learning.

From the aforementioned explanation, there are four essential elements to be focused on understanding the process of learning as presented on the following points:

a. A temporal changes on behaviour like being drunk, exhaustive, bored are not classified as learning;

b. Individual interaction shows that reaction occurs between two people. This reflects that learning is hypothetical situation which can only be recognized through measurable academic development;

c. Mental activity determines the learning progress, whether it is decreasing or improving lies much on the inner motivation;

d. Learning as a function shows that a process includes practicing and drilling in supporting students achieving their target.

Based on the these explanation, the researcher intends to discuss further regarding the relation between students' learning motivation and teachers' pedagogic competence toward the students achievement in social science subject. The researcher has also put some details regarding the common problems that students face to improve their achievement such as learning environment, learning motivation, teachers' pedagogic competence, learning discipline, media, and the effect of IQ toward the learning achievement

\section{Method}

This present study used two independent variables, learning motivation (X1) and teachers' pedagogic competence (X2) and one dependent variable which is the learning achievement in social science subject (Y). This study is conducted to the eighth graders of junior secondary school in Golewa district, Ngada regency. Those schools are SMPN IV Golewa, SMPN V Golewa, and SMP Soegija Pranatha. The students from these three schools are then selected as the sample of the study. The data are collected through questionnaire and test. They are further analysed statistically and descriptively to provide the data distribution, table, histogram and tendency central score from each variable, while inferential statistics are employed to know the coefficient correlation score and the coefficient regression for concluding the study. The constellation of the variables can be seen as follows:

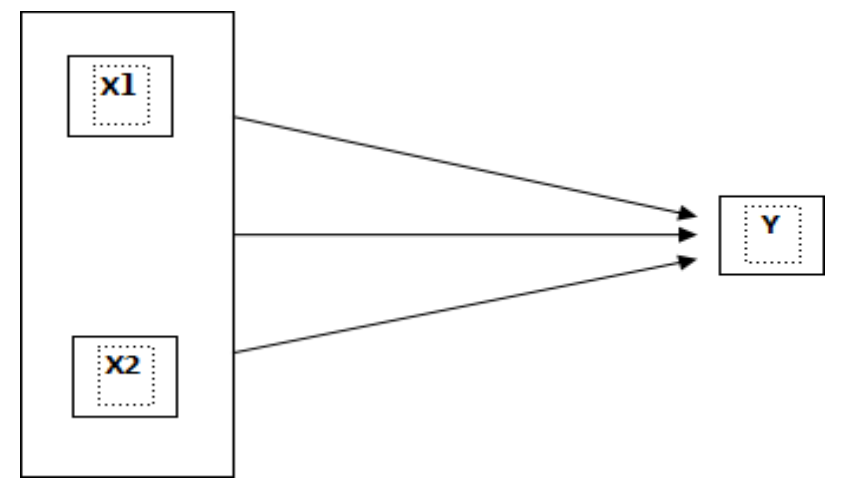

Figure 1. Research Design

Note:

X1 : Learning Motivation

X2 : Teachers Pedagogic Competence

Y : Learning Achievement in Social Science Subject 


\section{Findings and Discussion}

The first hypothesis testing is seeking the relation between learning motivation $\left(\mathrm{X}_{1}\right)$ and learning achievement in social science (Y). The hypothesis is presented as follows:

This Means:

$$
\begin{aligned}
& \mathrm{H}_{0}: \beta_{\mathrm{y} .12}=0 \\
& \mathrm{H}_{1}: \beta_{\mathrm{y} .12} \neq 0
\end{aligned}
$$

$\mathrm{H}_{0}$ : There is no correlation between students' learning motivation and students learning achievement

$\mathrm{H}_{1}$ : There is a correlation between students' learning motivation and students learning achievement

In order to prove that hypothesis, the researcher conducted correlation coefficient testing, particularly on testing the correlation between independent variable $\mathrm{X}_{1}$ (students' learning motivation) and the dependent variable Y (students' learning achievement). The calculation of correlation coefficient is assisted by software named SPSS 16. The program calculates the data with criteria of testing and results in deciding the significance of the correlation.

Table 1. Result of Correlation Coefficient between $\mathrm{X}_{1}$ and $\mathrm{Y}$

\begin{tabular}{|c|c|c|c|c|c|}
\hline $\begin{array}{c}\text { Mode } \\
\mathrm{I}\end{array}$ & $\mathrm{R}$ & $\mathrm{R}$ Square & $\begin{array}{c}\text { Adjusted R } \\
\text { Square }\end{array}$ & $\begin{array}{c}\text { Std Error of } \\
\text { the Estimated }\end{array}$ & $\begin{array}{c}\text { Durbin- } \\
\text { Watson }\end{array}$ \\
\hline 1 & $564^{2}$ & .318 & .308 & 3.061 & 2139 \\
\hline
\end{tabular}

b. Predictors (constant), Learning Motivation

The previous table shows the correlation coefficient is 0.546 , this means the correlation between learning motivation and the learning achievement is categorized as moderate. The information whether it is significant or not is provided in the last row of the table. By using two ways testing with significance level 5\%, it is concluded that there is a significant correlation between students' learning motivation $\left(\mathrm{X}_{1}\right)$ and students' learning achievement (Y).

In the like manner, the coefficient of determination results in 0.318 or $31.8 \%$, this shows the contribution of students learning motivation toward the learning achievement is $31.80 \%$, and for the rest which is $68.20 \%$, is determined by other factors that cannot be explained in the present study. The functional correlation between $\mathrm{X}_{1}$ and $\mathrm{Y}$ can also be presented in a form of regression equation assisted with computer calculation through SPSS

Table 2. The Result of Calculation on Regression Line between Variable $\mathrm{X}_{1}$ and Variable $\mathrm{Y}$

$$
\text { Coefficients }
$$

\begin{tabular}{|c|c|c|c|c|c|}
\hline \multirow{2}{*}{ Model } & \multicolumn{2}{|c|}{ Unstandardized coefficient } & $\begin{array}{c}\text { Standardized } \\
\text { Coefficient }\end{array}$ & \multirow{2}{*}{$\mathrm{t}$} & \multirow{2}{*}{ Sig } \\
\cline { 2 - 4 } & $\mathrm{B}$ & Std Error & Beta & & \\
\hline 1 Constanta of & 33.916 & 2.026 & 564 & 16.744 & 000 \\
Learning Motivation & 309 & 055 & & 5.628 & 000 \\
\hline
\end{tabular}

a. Dependent Variable Learning Achievement

Based on the table above, the equation of regression line represents the correlation between variable $\mathrm{X}_{1}$ and variable $\mathrm{Y}$ which is $\hat{\boldsymbol{Y}}=33.916+0.309$. In order to test the hypothesis where it is assumed that there is a correlation between students' learning motivation $\left(\mathrm{X}_{1}\right)$ and variable $\mathrm{Y}$ (students' learning achievement), regression coefficient testing is conducted.

This calculation also requires assistance from SPSS 16. Based on the provision, the criteria for regression coefficient testing is formulated as follows, "if $\mathrm{p}$ value ( $\mathrm{sig}$ ) $>0.05, \mathrm{H}_{0}$ is accepted", this means the coefficient is not significant, in other words, there is a significant correlation between independent variable $\mathrm{X}$ and variable Y. p value (sig) is the number presented on column sig and regression row in the ANOVA table, then computated through SPSS 16

Table 3. Result of Regression Coefficient Testing between Variable $\mathrm{X}_{1}$ and Variable $\mathrm{Y}$ ANOVA

\begin{tabular}{|l|c|c|c|c|c|}
\hline \multicolumn{1}{|c|}{ Model } & $\begin{array}{c}\text { Sum of } \\
\text { Squares }\end{array}$ & Df & $\begin{array}{c}\text { Mean } \\
\text { Square }\end{array}$ & f & Sig \\
\hline 1. Regression & 296.776 & T & 296.776 & 31.678 & $000^{2}$ \\
Residual & 637.067 & 68 & 9.369 & & \\
Total & 933.843 & 69 & & & \\
\hline
\end{tabular}

a. Predictors (Constant), Learning Motivation

b. Dependent Variable. Learning Achievement 
From table 3 , it is shown that $\mathrm{p}$ value $(\mathrm{sig})=0.00<0.005$, thus $\mathrm{H}_{0}$ is rejected. This also means that the regression coefficient is significant.

a. The correlation between teachers' pedagogic competence $\left(\mathrm{X}_{2}\right)$ and students learning achievement (Y)

The hypothesis of this correlation can be seen as follows:

Definition:

$$
\begin{aligned}
& \mathrm{H}_{0} ; \beta_{\mathrm{y} 1}=0 \\
& \mathrm{H}_{1} ; \beta_{\mathrm{y} 1} \neq 0
\end{aligned}
$$

$\mathrm{H}_{0} \quad$ : There is no significant correlation between teachers' pedagogic competence and students learning achievement

$\mathrm{H}_{1} \quad$ : There is significant correlation between teachers' pedagogic competence and students learning achievement

In proving this hypothesis, correlation coefficient testing is conducted, specifically on proving the correlation between teachers' pedagogic competence $\left(\mathrm{X}_{2}\right)$ and students' learning achievement (Y). The calculation of correlation coefficient and its testing are assisted with SPSS 16 software. The significance of the correlation will be determined from annotation in the last row of the table of calculation.

\begin{tabular}{|c|c|c|c|c|c|}
\hline \multicolumn{6}{|c|}{ Model Summary } \\
\hline Model I & $\mathrm{R}$ & R. Suquare & $\begin{array}{l}\text { Adjusted } \\
\text { Square }\end{array}$ & $\begin{array}{l}\text { Std. Error of } \\
\text { Estimate }\end{array}$ & $\begin{array}{l}\text { Durbin- } \\
\text { Watson }\end{array}$ \\
\hline 1 & $.803^{2}$ & .645 & .639 & 2.209 & 1.999 \\
\hline
\end{tabular}

Table 4. Result of Correlation Coefficient Test between Variable $\mathrm{X}_{2}$ and Variable $\mathrm{Y}$

From the presented table, it is shown that coefficient correlation results in 0.803 . This signifies the significant correlation between teachers' pedagogic competence and students learning achievement is 0.803 and it is categorized as highly correlated. The decision whether it is significant or not is located at the last row of the table where the test employs two ways testing with significance level 5\%. In conclusion, there is a high correlation between teachers' pedagogic competence and students' learning achievement. Meanwhile, the determination coefficient shows a result 0.645 or $64.50 \%$. This reflects that teachers' pedagogical competence influences $64.50 \%$ of students' learning achievement, while the other $35.50 \%$ cannot be explained in this present study. The functional correlation between $\mathrm{X}_{2}$ and $\mathrm{Y}$ is also presented in a form of regression equation in the SPSS

Table 5. The Result of Regression Line in the Correlation of Variable X2 and Variable Y Coefficients

\begin{tabular}{|c|c|c|c|c|c|}
\hline \multirow{2}{*}{ Model } & \multicolumn{2}{|c|}{ Unstandardized coefficient } & $\begin{array}{c}\text { Standardized } \\
\text { Coefficient }\end{array}$ & \multirow{2}{*}{$\mathrm{t}$} & \multirow{2}{*}{ Sig } \\
\cline { 2 - 4 } & $\mathrm{B}$ & Std Error & Beta & & \\
\hline $\begin{array}{c}\text { 1 Constanta of } \\
\text { pedagogical } \\
\text { competence }\end{array}$ & 29.400 & 1.441 & 803 & 20.409 & 000 \\
& 398 & .036 & & 11.107 & 000 \\
\hline
\end{tabular}

a. Dedependent Variable: Learning Achievement

From the table above we can see that the regression line that represents the correlation between $\mathrm{X}_{2}$ and $\mathrm{Y}$ is $\hat{\mathrm{Y}}=29.400+0.398$. In order to test the hypothesis which there is a correlation between teachers' pedagogic competence $\left(\mathrm{X}_{2}\right)$ and students' learning achievement $(\mathrm{y})$, the regression coefficient test is administered. This calculation, likewise the previous calculation, is also assisted by SPSS 16. According to the provision, , the criteria for regression coefficient testing is formulated as follows, "if $\mathrm{p}$ value ( $\mathrm{sig})>0.05, \mathrm{H}_{0}$ is accepted", this means the coefficient is not significant, in other words, there is a significant correlation between independent variable $\mathrm{X}$ and variable $\mathrm{Y}$. $\mathrm{p}$ value ( $\mathrm{sig}$ ) is the number presented on column sig and regression row in the ANOVA table, then computated through SPSS 16. 
Table 6. Result of Regression Coefficient Test in the Correlation between Variable $\mathrm{X}_{2}$ and Variable $\mathrm{Y}$

\begin{tabular}{|l|c|c|c|c|c|}
\hline \multicolumn{1}{|c|}{ Model I } & $\begin{array}{c}\text { Sum of } \\
\text { Square }\end{array}$ & df & $\begin{array}{c}\text { Mean } \\
\text { Square }\end{array}$ & F & Sig \\
\hline 1 Total of & 601.994 & 1 & 601.994 & 123.356 & $000^{2}$ \\
Regression & 331.849 & 68 & 4.880 & & \\
Residual & 933.843 & 69 & & \\
\hline
\end{tabular}

a. Predictors (Constant) Teachers' Pedagogic Competence

b. Dependent Variable: Students' Learning Achievement

From table 6 , it is clear that $\mathrm{p}$ value $(\mathrm{sig})=0,00<0,005$, thus, $\mathrm{H}_{0}$ is rejected or meaning that the regression coefficient is significant.

As for the hypothesis that state, "there is correlation between students' learning motivation $\left(\mathrm{X}_{1}\right)$ and teachers' pedagogic competence $\left(\mathrm{X}_{2}\right)$ toward students' learning achievement $(\mathrm{Y})$. It is also formulated as the following ;

$$
\begin{aligned}
& \mathrm{H}_{0 ;} \beta \gamma 12=0 \\
& \mathrm{H} 1 ; \beta \gamma 12 \neq 0
\end{aligned}
$$

Definition;

$\mathrm{H}_{0}$ : There is no correlation between students' learning motivation and teachers' pedagogic competence toward the students' learning achievement in social science subject

$\mathrm{H}_{1}$ : There is correlation between students' learning motivation and teachers' pedagogic competence toward the students' learning achievement in social science subject

In its process of proving the hypothesis, correlation coefficient test is conducted, particularly to know the degree of relationship between students learning motivation $\left(\mathrm{X}_{1}\right)$ and teachers' pedagogic competence $\left(\mathrm{X}_{2}\right)$ toward students' learning achievement in social science subject (Y). In the like manner, this phase will also utilise SPSS as a tool to help the researcher calculating the correlation coefficient.

Table 7. Result of Correlation Coefficient Test on the Degree of Relation between Variable $\mathrm{X}_{1}$ and $\mathrm{X}_{2}$ toward $\mathrm{Y}$ Model Summary

\begin{tabular}{rl|c|c|c|c|c|}
\hline \multicolumn{2}{|c|}{$\begin{array}{c}\text { Model } \\
\mathrm{I}\end{array}$} & $\mathrm{R}$ & R Square & $\begin{array}{c}\text { Adjusted R } \\
\text { Square }\end{array}$ & $\begin{array}{c}\text { Std. Error of } \\
\text { the Estimate }\end{array}$ & $\begin{array}{c}\text { Durbin- } \\
\text { Watson }\end{array}$ \\
\hline 1 & $.803^{2}$ & .645 & .634 & 2.225 & 1.999 \\
\hline
\end{tabular}

From table 7 we can see clearly that the two predictors have a degree of relationship in number of 0.803. This means both the correlation between students' learning motivation and teachers' pedagogic competence simultaneously related to the students' learning achievement and classified as highly related.

As for the determination coefficient, it shows $64.50 \%$. This reflects that students' learning motivation altogether with teachers' pedagogic competence have influenced $64.50 \%$ of students learning achievement. While $35.50 \%$ cannot be explained because they are influenced by other factors which are not mentioned in this present study. The calculation of the predictors $\mathrm{X}_{1}, \mathrm{X}_{2}$, toward $\mathrm{Y}$ has also been based on SPSS 16 .

Table 8. Result of Regression Line Test on Degree of Correlation Between $\mathrm{X}_{1}, \mathrm{X}_{2}$, Toward Y Coefficient

\begin{tabular}{|c|c|c|c|c|c|}
\hline \multirow{2}{*}{ Model } & \multicolumn{2}{|c|}{ Unstandardized coefficient } & $\begin{array}{c}\text { Standardized } \\
\text { Coefficient }\end{array}$ & \multirow{2}{*}{$\mathrm{t}$} & \multirow{2}{*}{ Sig } \\
\cline { 2 - 4 } & $\mathrm{B}$ & Std Error & Beta & & \\
\hline 1 (Constant) & 29.372 & 1.582 & 005 & 18.562 & 000 \\
Learning motivation & 002 & 056 & 800 & 045 & 955 \\
Teachers' competence & 396 & 051 & & 7.850 & 000 \\
\hline
\end{tabular}

a. DDependent Variable: Learning Achievement

Table 9. Result of Regression Coefficient Test on The Degree Of Correlation Between Variable $\mathrm{X}_{1}, \mathrm{X}_{2}$, Toward Y

ANOVA

\begin{tabular}{|l|c|c|c|c|c|}
\hline \multicolumn{1}{|c|}{ Model I } & $\begin{array}{c}\text { Sum of } \\
\text { Square }\end{array}$ & Df & $\begin{array}{c}\text { Mean } \\
\text { Square }\end{array}$ & F & Sig \\
\hline 1 Regression & 602.004 & 2 & 301.002 & 60.774 & $000^{2}$ \\
Residual & 331.839 & 67 & 4.953 & & \\
Total & 933.843 & 69 & & & \\
\hline
\end{tabular}


a. Predictors (Constant), teachers' pedagogic competence, students' learning motivation

b. Dependent Variable: Learning Achievement

Table 8 has shown us the regression line that represents the degree of correlation between $\mathrm{X}_{1}$ and $\mathrm{X}_{2}$ toward variable $\mathrm{Y}$ with $\mathrm{Y}=29.372+0.002 \mathrm{X}_{1}+0.396 \mathrm{X}_{2}$. In order to test the hypothesis that there is a positive correlation between students' learning motivation $\left(\mathrm{X}_{1}\right)$, teachers' pedagogic competence $\left(\mathrm{X}_{2}\right)$ toward the students learning achievement in social science subject (Y), a regression coefficient test is administered. The calculation will be based on computer assisted SPSS 16. The criteria for regression coefficient testing is formulated as follows, "if $\mathrm{p}$ value ( $\mathrm{sig})>0.05, \mathrm{H}_{0}$ is accepted", this means the coefficient is not significant, in other words, there is a significant correlation between independent variable $X$ and variable $Y$. $p$ value (sig) is the number presented on column sig and regression row in the ANOVA table, then computated through SPSS 16.

From table 9 , it is clear that the $\mathrm{p}$ value $(\mathrm{sig})=0.000<0.005$, which means that $\mathrm{H}_{0}$ is rejected. This also means that the regression coefficient is significant. In conclusion, there is a high correlation between students' learning motivation $\left(\mathrm{X}_{1}\right)$, teachers pedagogic competence $\left(\mathrm{X}_{2}\right)$ toward the students' learning achievement in social science subject (Y).

\section{Discussion}

This present study aims at investigating the correlation between students' learning motivation, teachers pedagogic competence, toward the students' learning achievement. From the aforementioned data, it is gained that the correlation coefficient is 0.546 . The degree of relation between students' learning motivation and their achievement is classified as moderate. The decision whether or not the predictor is significant is located at the last row of the table with significance level of $5 \%$. In other words, there is a correlation between students' learning motivation and $\left(\mathrm{X}_{1}\right)$ toward students' learning achievement $(\mathrm{Y})$. The calculation on the coefficient determination shows $31.80 \%$. This reflects that the contribution of students motivation to the students' learning achievement is $31.80 \%$. Meanwhile, the other $68.20 \%$ is influenced by other factors which cannot be explained in this present study.

Furthermore, the investigation on students' motivation toward students' ability in writing shows that the result is 0.803 , meaning that the degree of correlation between teachers' pedagogic competence and students' learning achievement is 0.803 and being classified as strong correlation. The decision whether or not the predictor has a strong correlation is based on the last row of the table that shows it with $5 \%$ level of significance. In other words, there is a positive correlation between teachers' pedagogic competence $\left(\mathrm{X}_{2}\right)$ and students' learning achievement in social science subject. On the other hand, the determination coefficient shows 0.645 or $64.50 \%$. This means the teachers' pedagogic competence affects $64.50 \%$ of the students' learning achievement, while the rest $35.50 \%$ is influenced by other factors that cannot be explained in this study.

Moreover, the students' learning motivation and teachers' pedagogic competence as predictors have a significant correlation toward students' learning achievement which is reflected by the correlation coefficient with 0.803 and classified as strongly correlated.

\section{Conclusion}

As the researcher has presented the findings, it is concluded that (1) there is a correlation between students' learning motivation $\left(\mathrm{X}_{1}\right)$ and teachers' pedagogic competence $\left(\mathrm{X}_{2}\right)$ toward the students learning achievement in social science subject $(\mathrm{Y})$ is rejected because there is a strong correlation which is reflected by the sig value which is $<0.05$ (students' learning motivation sig $=0.000>0.05$, teachers' pedagogic competence sig. $=0.000<0.05)$. This means that the $\mathrm{H}_{0}$ is rejected. To put it in another way, the hypothesis that there is a correlation between students' learning motivation altogether with teachers' pedagogic competence toward students' learning achievement is accepted. (2) there is a positive correlation between students' learning motivation $\left(\mathrm{X}_{1}\right)$ and the students' learning achievement $(\mathrm{Y})$ is rejected because sig. $=0.000<0.05$. This means the $\mathrm{H}_{0}$ is rejected. In other words, the hypothesis that states there is a positive correlation between students' learning motivation and students' learning achievement is accepted. (3) There is a correlation between teachers' pedagogic competence $\left(\mathrm{X}_{2}\right)$ and the students learning achievement in social science subject $(\mathrm{Y})$ is rejected because sig. $=0.000>0.05$. This means $\mathrm{H}_{0}$ is rejected. In other words, the hypothesis that states there is a positive correlation between teachers' pedagogic competence and students' learning achievement in social science subject is accepted. 


\section{References}

Gunawan, A.H. (1996). Administrasi Sekolah Administrasi Pendidikan Makro. Jakarta : Rineka Cipta Hasan, A.M. (2003). Pengembangan Profesionalisme Guru Di Abad Pengetahuan. Malang

Hasibuan, H. Malayu SP. 1996. Organisasi dan Motivasi Dasar Peningkatan Produktifitas. Jakarta: Bumi Aksara

Iska, Z.N. (2006). Psikologi Pengantar Pemahaman Diri dan Lingkungan Bahan Kuliah dan Diskusi Mahasiswa, Cet. Ke. 1. Jakarta : Kizi Brother

Kirkpatrik, T.O and Chad, T.L. (1995). Effetive Supervision Preparing for 21st Century. Orlando : The Dryden Press

Kumpulan UU dan PP RI tentang Pendidikan. (2007). Jakarta: Depag

Luthan, F. (1995). Organizational Behavior. Singapore : McGraw Hill

PP Nomor 19 Tahun 2005 Tentang Standar Nasional Pendidikan. Jakarta : Eka Jaya

Purwanto. (2002). Profesionalisme Guru. Teknodik, 10(6)

Rakhmat, J. (1999). Psikologi Komunikasi, Bandung: Remaja Rosdikarya

Richard, D. (1997). Sukses Memotivasi Juru-Jurus Meningkatkan Prestasi. Jakarta: Gramedia Pustaka Utama

Sabri, A. (1995). Psikologi Pendidikan. Jakarta Pedoman ilmu jaya

Sudjana, N. (2002). Dasar-Dasar Proses Belajar Mengajar. Bandung: Sinar Baru

Sukidi. (2004). Kecerdasan Spiritual Mengapa SQ Lebih Penting Daripada IQ dan EQ. Jakarta : Gramedia Pustaka Utama

Supriadi. (2003). Dedi Guru di Indonesia, Pendidikan, Pelatihan dan Perjuangannya Sejak Zaman Kolonial Hingga Era Reformasi. Jakarta : Depdiknas

Suryabrata, S. (1995). Psikologi Pendidikan. Jakarta: Rajawali Pers

Suwarto, F.X. (1999). Perilaku Keorganisasian. Yogyakarta: Universitas Atmajaya

Thoha, M. (2004). Perilaku Organisasi : Konsep Dasar dan Aplikasinya. Jakarta: PT Grasindo)

Usman, M. U. (2000). Menjadi Guru Profesional. Bandung: Remaja Rosdakarya)

Winkel, W.S. (1996). Psikologi Pengajaran, Edisi yang Disempurnakan, Cetakan ke-4. Jakarta Grasindo) 